\title{
The Emerging Role of Epitranscriptomics in Cancer: Focus on Urological Tumors
}

\author{
João Lobo ${ }^{1,2,3}\left(\mathbb{D}\right.$, Daniela Barros-Silva ${ }^{1}\left(\mathbb{D}\right.$, Rui Henrique ${ }^{1,2,3} \mathbb{D}$ and Carmen Jerónimo ${ }^{1,3, *(\mathbb{D})}$ \\ 1 Cancer Biology and Epigenetics Group, Research Center of Portuguese Oncology Institute of Porto \\ (GEBC CI-IPOP), R. Dr. António Bernardino de Almeida, 4200-072 Porto, Portugal; \\ joaomachadolobo@gmail.com (J.L.); daniela.barros.silva94@gmail.com (D.B.-S.); \\ henrique@ipoporto.min-saude.pt (R.H.) \\ 2 Department of Pathology, Portuguese Oncology Institute of Porto (IPOP), R. Dr. António Bernardino \\ de Almeida, 4200-072 Porto, Portugal \\ 3 Department of Pathology and Molecular Immunology, Institute of Biomedical Sciences Abel Salazar, \\ University of Porto (ICBAS-UP), Rua Jorge Viterbo Ferreira 228, 4050-513 Porto, Portugal \\ * Correspondence: carmenjeronimo@ipoporto.min-saude.pt or cljeronimo@icbas.up.pt; Tel.: +351-225-084-000
}

Received: 28 September 2018; Accepted: 8 November 2018; Published: 13 November 2018

\begin{abstract}
Epitranscriptomics has gained ground in recent years, especially after the advent of techniques for accurately studying these mechanisms. Among all modifications occurring in RNA molecules, N6-methyladenosine $\left(\mathrm{m}^{6} \mathrm{~A}\right)$ is the most frequent, especially among mRNAs. $\mathrm{m}^{6} \mathrm{~A}$ has been demonstrated to play important roles in many physiological processes and several disease states, including various cancer models (from solid to liquid tumors). Tumor cells' epitranscriptome is indeed disrupted in a way to promote cancer-prone features, by means of up/downregulating $\mathrm{m}^{6} \mathrm{~A}$-related players: the so-called writers, readers and erasers. These proteins modulate $\mathrm{m}^{6} \mathrm{~A}$ establishment, removal and determine mRNAs fate, acting in a context-dependent manner, so that a single player may act as an oncogenic signal in one tumor model (methyltransferase like 3 (METTL3) in lung cancer) and as a tumor suppressor in another context (METTL3 in glioblastoma). Despite recent advances, however, little attention has been directed towards urological cancer. By means of a thorough analysis of the publicly available TCGA (The Cancer Genome Atlas) database, we disclosed the most relevant players in four major urogenital neoplasms-kidney, bladder, prostate and testicular cancer-for prognostic, subtype discrimination and survival purposes. In all tumor models assessed, the most promising player was shown to be Vir like $\mathrm{m}^{6} \mathrm{~A}$ methyltransferase associated (VIRMA), which could constitute a potential target for personalized therapies.
\end{abstract}

Keywords: bladder cancer; epitranscriptomics; eraser; kidney cancer; $\mathrm{m}^{6} \mathrm{~A}$; prostate cancer; reader; RNA modifications; testicular cancer; writer

\section{RNA Modifications in Brief: From Epigenetics to Epitranscriptomics}

In the past few years, RNA modifications have caught the scientific community's attention. Expanding the scope of epigenetics, which comprises a group of chromatin-based mechanisms including chemical and conformational modifications of DNA and/or histones [1], "epitranscriptomics" (also called "RNA Epigenetics" [2]) relates to modifications in RNA molecules, and has emerged as a pivotal player in several biologic and disease processes [3].

More than 140 RNA modifications have been discovered so far [4-6] including, for instance, methylation (N7-methylguanosine $\left[\mathrm{m}^{7} \mathrm{G}\right]$, N6-methyl-2'-O-methyladenosine $\left[\mathrm{m}^{6} \mathrm{Am}\right]$, $2^{\prime}$-O-methylation $[\mathrm{Nm}], \mathrm{N} 6$-methyladenosine $\left[\mathrm{m}^{6} \mathrm{~A}\right], \mathrm{N} 1$-methyladenosine $\left[\mathrm{m}^{1} \mathrm{~A}\right], 5$-methylcytosine $\left[\mathrm{m}^{5} \mathrm{C}\right]$ and 5-hydroxymethylcytosine $\left[\mathrm{hm}^{5} \mathrm{C}\right]$ ), RNA editing (adenosine-to-inosine (A-to-I), 
pseudo-uridine $(\psi)$, among others $[7,8])$. New modifications are emerging every day, such as KDka427 (a modification with a thioacetal structure [4]). They have been reported in various types of RNAs, including messenger (mRNAs) and noncoding (ncRNAs), such as transfer (tRNAs), ribosomal (rRNAs), small nuclear (snRNAs) and long noncoding (lncRNAs) [5]. Importantly, contrarily to DNA modifications that primarily regulate gene transcription, RNA modifications regulate the many aspects of RNAs fate, including localization, splicing, nuclear export, targeting for destruction, stability, secondary structure and efficiency of translation, ultimately allowing the formation of a functional RNA molecule. They accomplish this in a context-dependent manner, being site-specific and RNA-species-specific (i.e., the same modification can have opposing effects depending on the context it occurs in) [9].

Among RNA modifications, $\mathrm{m}^{6} \mathrm{~A}$ (first reported in 1974 [10], but not given full acceptance until the advent of methodologies for mapping its location) is the most abundant in eukaryotic mRNAs and lncRNAs $\left(\mathrm{m}^{6} \mathrm{~A} / \mathrm{A}=0.1-0.6 \%\right)$ [11], and will be the focus of this review. It is not randomly distributed across transcripts, being particularly enriched at $3^{\prime}$ untranslated regions ( $\left.3^{\prime} \mathrm{UTRs}\right)$, around stop codons and within internal long exons [7,12-14]. The finding of this non-random post-transcriptional mRNA methylation pattern (the mRNA "epitranscriptome"), along with the discovery of adenosine methyltransferases ("writers"), $\mathrm{m}^{6} \mathrm{~A}$ demethylating enzymes ("erasers") and $\mathrm{m}^{6} \mathrm{~A}$ binding proteins ("readers"), indicate that mRNAs undergo methylation as a fine-tuning mechanism which reversibly and dynamically regulates their overall activity (similar to methylation of DNA molecules) $[15,16]$.

$\mathrm{m}^{6} \mathrm{~A}$ has been shown to play important roles in regulating gene expression and phenotypes in both health and disease. In this line, great effort has been made to find and improve methodologies for detecting and profiling these alterations (with transcriptome-wide analysis being considered "Method of the Year" by Nature Methods [17]), and new methodologies with different approaches are being uncovered every day $[11,18,19] . \mathrm{m}^{6} \mathrm{~A}$ is, indeed, the most prevalent internal modification of mRNAs. Its respective writer (methyltransferase like 3 (METTL3), which writes the methyl code onto RNA) along with other components of the methylation complex (METTL14, METTL4, METTL16, Wilms Tumor 1-Associating Protein (WTAP), Vir like $\mathrm{m}^{6} \mathrm{~A}$ methyltransferase associated (KIAA1429/VIRMA), RNA binding motif protein 15 (RBM15), RBM15B), its erasers (proteins that remove the methyl code from RNA, such as fat mass and obesity related (FTO) and $\alpha$-ketoglutarate dependent dioxygenase 5 (ALKBH5)) and its readers (proteins that recognize $\mathrm{m}^{6} \mathrm{~A}$, decode it and transform it into a functional signal, targeting RNAs for their final destination and initiating downstream processes, such as YTH domain family proteins (YTHDF) 1, 2 and 3, YTH domain-containing proteins (YTHDC) 1 and 2, eukaryotic initiation factor 3 (eIF3), heterogeneous nuclear ribonucleoprotein $\mathrm{C}$ (HNRNPC) and heterogeneous nuclear ribonucleoprotein A2-B1 (HNRNPA2B1)) have been already identified (Figure 1); these facts, in parallel with the improvement of methodology for accurately profiling $\mathrm{m}^{6} \mathrm{~A}$, have increased the interest in studying the impact of modifying $\mathrm{m}^{6} \mathrm{~A}$ levels by changing the expression of these proteins in various disease states $[8,14,20-24]$. 


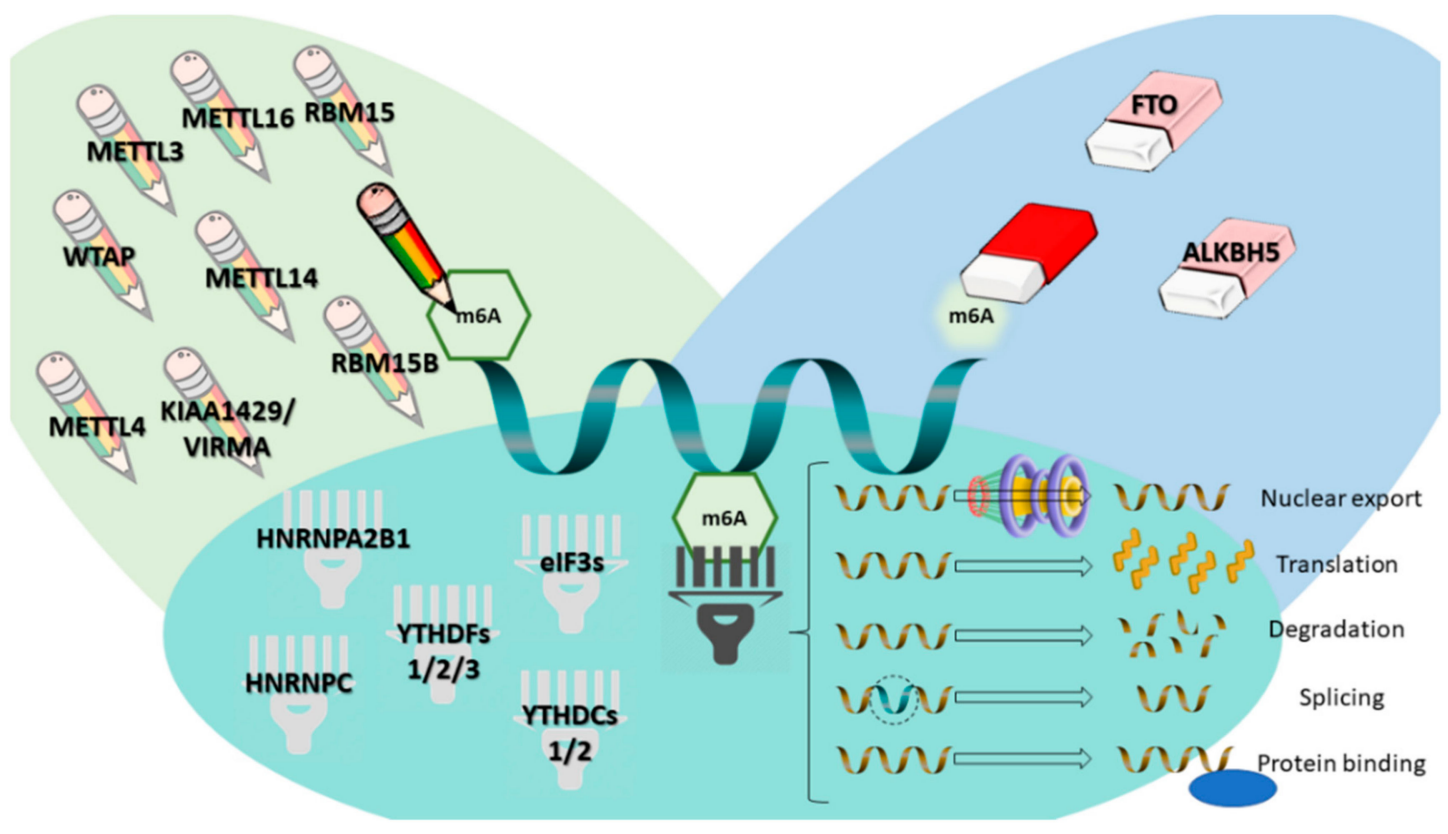

Figure 1. $\mathrm{m}^{6} \mathrm{~A}$ modification and $\mathrm{m}^{6} \mathrm{~A}$-related proteins (writers, erasers and readers), and their respective functions. Writers are illustrated as "pencils", erasers as "pencil erasers" and readers as "barcode readers." METTL4, 14, 3, 16-methyltransferase like 4, 14, 3 or 16; KIAA1429/VIRMA-Vir like $\mathrm{m}^{6} \mathrm{~A}$ methyltransferase associated; RBM15 or 15B-RNA binding motif protein 15 or 15B; FTO - fat mass and obesity associated; ALKBH5- $\alpha$-ketoglutarate dependent dioxygenase 5; WTAP -Wilms' tumor 1-associating protein; YTHDF 1, 2 and 3-YTH domain family proteins 1, 2 and 3; YTHDC 1 and 2-YTH domain-containing proteins 1 and 2; eIF3-eukaryotic initiation factor 3; HNRNPC - heterogeneous nuclear ribonucleoprotein C; HNRNPA2B1-heterogeneous nuclear ribonucleoprotein A2-B1; $\mathrm{m}^{6} \mathrm{~A}-\mathrm{N} 6$-methyladenosine.

In this vein, $\mathrm{m}^{6} \mathrm{~A}$ has been explored in many perspectives and different contexts in the past few years, having been shown to play important roles in very diverse biological mechanisms and related diseases, including metabolism/obesity, circadian rhythm, immune response, viral replication, gametogenesis/infertility, embryogenesis/stem cell differentiation, neurologic development/deficits, and also in cancer [3,16,25-39].

\section{2. $\mathrm{m}^{6} \mathrm{~A}$ Modification in Non-Urological Malignancies: Literature Review}

The epitranscriptome of cancer cells has been demonstrated to be disrupted [40], and associations with dysregulation of expression of $\mathrm{m}^{6} \mathrm{~A}$-related proteins (i.e., their writer, readers and erasers) have been increasingly found in many neoplasms [41]. It is reasonable to think that, by modifying the epitranscriptome, tumor cells modify the fate of many target transcripts, which might influence many aspects of cancer progression, including growth and proliferation, invasiveness, migration and metastatic spread, stemness maintenance and differentiation, response to immune surveillance and to stress, among others [21]. Again, and in accordance with the context-dependent role of RNA modifications, evidence has shown that both writers and erasers can assume an oncogenic or tumor suppressor role in different tumor models (for instance, the writer METTL3 may act as oncogene in lung adenocarcinoma and as tumor suppressor in glioblastoma) [21,42].

Modifications in $\mathrm{m}^{6} \mathrm{~A}$ levels and/or $\mathrm{m}^{6} \mathrm{~A}$-related proteins expression have been found in a broad spectrum of cancer types. Thus, targeting $\mathrm{m}^{6} \mathrm{~A}$ regulatory mechanisms might constitute a new form of cancer treatment [43], especially for suppressing cancer stem cells [42,44]. Clinical trials with drugs targeting oncogenic regulators of the epitranscriptome (such as FTO inhibitors like Citrate and R-2-hydroxyglutarate (R-2HG)) are needed and expected for the near future [37,45]. 
Polymorphisms in intron 1 of FTO have been associated with a higher risk for development of many neoplasms; however, a metanalysis concluded that, except for pancreatic cancer, the risk was mainly due to body mass index (BMI) [46,47]. However, a single-nucleotide polymorphism (SNP) in FTO intron 8 was found to be associated with a higher risk for melanoma [48], and, as for breast cancer (BCa), another SNP in FTO intron 1 was identified as a susceptibility locus for estrogen-negative BCa [49], both not explained by BMI. FTO was also overexpressed in BCa (particularly in human epidermal growth factor receptor 2 (HER2)-positive tumors) and was also shown to play a role in triple-negative, pan-resistant, inflammatory breast cancer cell lines [50,51]. Also in $\mathrm{BCa}$, a link between hypoxia, tumor invasiveness / metastasis and $\mathrm{m}^{6} \mathrm{~A}$ has been proposed, with hypoxia-inducible factors (HIFs) leading to increased mRNA expression of the pluripotency factor homeobox transcription factor Nanog (NANOG) (and subsequent BCa stem cells specification) by means of $\mathrm{m}^{6} \mathrm{~A}$ demethylation by the eraser ALKBH5 [52,53]. Furthermore, a positive feedback loop involving HBXIP/miR let-7g/METTL3 was reported to promote BCa progression and proliferation [54].

The writer METTL3 was also shown to be upregulated in various solid tumors, including hepatocellular carcinoma, associated with poor prognosis. In this tumor model, METTL3-mediated $\mathrm{m}^{6} \mathrm{~A}$ modification targets suppressor of cytokine signaling 2 (SOCS2), promoting its degradation, in a process dependent of YTHDF2 reader [55]. More recently, YTHDF1 proved also to be upregulated in hepatocellular carcinoma, associated with more advanced stages and poorer survival, contrarily to METTL14, which promotes metastatic potential when downregulated [56,57]. In addition, $\mathrm{m}^{6} \mathrm{~A}$ and related proteins are implicated in treatment resistance, as shown in pancreatic cancer cells, in which knockdown of the writer METTL3 improved sensitivity to both chemo- and radiation therapy [58], clearly demonstrating the rationale for using treatments targeting $\mathrm{m}^{6} \mathrm{~A}$ modulators. Finally, the reader YTHDF2 was shown to display both diagnostic and prognostic value in pancreatic cancer and to regulate the epithelial-to-mesenchymal transition (EMT) phenomenon [59], whereas WTAP was found to promote migration and invasion in cholangiocarcinoma [60].

Concerning colorectal cancer, the reader YTHDF1 seems to be of paramount importance in disease progression, with immunoexpression associating with unfavorable prognosis disease parameters and poorer survival. Again, the knockdown of YTHDF3 sensitized cancer cells to chemotherapy and, additionally, oncogene c-Myc was found to drive YTHDF1 expression [61]. Moreover, and besides the several RNA editing modifications reported, increased expression of the reader YTHDC2 in colorectal cancer promotes metastatic spread by upregulating hypoxia inducible factor 1 subunit $\alpha$ (HIF-1 $\alpha)[62,63]$. FTO overexpression was shown to impact on prognosis in gastric cancer patients, associated with poor differentiation, lymph node metastases, tumor stage and poor survival [64].

In cervical cancer, a lower amount of $\mathrm{m}^{6} \mathrm{~A}$ mRNA modification was associated with disease progression and poor prognosis (higher International Federation of Gynecology and Obstetrics (FIGO) stage, recurrence, metastases and survival), and further manipulation of $\mathrm{m}^{6} \mathrm{~A}$ levels in cell lines by altering the expression of respective writers and erasers resulted in increasing or decreasing disease aggressiveness, respectively [65]. More recently, it was demonstrated that the eraser FTO is also upregulated in cervical cancer and leads to chemo- and radiation therapy resistance by demethylating the mRNA transcripts of its target, $\beta$-catenin [66]. In addition, a recent study in endometrial cancer has elegantly shown that decreased $\mathrm{m}^{6} \mathrm{~A}$ caused by a mutation in METTL14 or downregulation of METTL3 ultimately leads to increased proliferation by activating the AKT signaling pathway [67].

$\mathrm{m}^{6} \mathrm{~A}$ modification in mRNA of glioblastoma stem cells regulates their capacity of self-renewal and tumorigenesis, with overexpression of writers (METTL3 and METTL14) and downregulation of erasers (FTO and ALKBH5) inhibiting tumor growth. In addition, high levels of the eraser ALKBH5 associated with poor prognostic features and METTL3 associated with radiation therapy resistance [68-70]. This finding may be explored as a potential therapeutic target. Moreover, in lung cancer, another aggressive neoplasm, METTL3 was shown to act as an oncogene, inducing tumor growth and proliferation, also promoting translation of important genes such as epidermal growth factor receptor (EGFR) and tafazzin (TAZ) [71]. An interaction between molecules like microRNAs and 
$\mathrm{m}^{6} \mathrm{~A}$ alterations was also depicted, with miR-33a inhibiting lung cancer cells proliferation by targeting METTL3 [72].

$\mathrm{m}^{6} \mathrm{~A}$ has been demonstrated to have an impact in biogenesis of hematolymphoid neoplasms, as well. It was shown that mutations in $\mathrm{m}^{6} \mathrm{~A}$-related proteins confer poor prognosis in acute myeloid leukemia (AML) [73]. Mutations in writers (METTL3, METTL14, WTAP, RBM15) promote and maintain leukemogenesis in AML [74-79], whereas overexpression of the eraser FTO in AML cell lines also promoted proliferation and decreased apoptosis [80]. Moreover, FTO plays a role in response to all-trans-retinoic acid (ATRA) and, interestingly, D-2-hydroxyglutarate (D2-HG) (the metabolite accumulated in isocitrate dehydrogenase 1 and 2 (IDH1/2)-mutant leukemias (20\% of AMLs)) functions as an inhibitor of FTO demethylase, meaning that FTO expression is context-dependent and has to be interpreted according to IDH mutational status [81,82]. A summary of the findings presented in this section is depicted in Table 1. 
Table 1. Review of the literature regarding $\mathrm{m}^{6} \mathrm{~A}$ modification and related proteins in non-urological malignancies.

\begin{tabular}{|c|c|c|c|c|}
\hline Tumor Model & Methodology & Outcome & Sample Size & Author (Ref.) \\
\hline \multirow{3}{*}{ Liver } & $\begin{array}{l}\text { MeRIP/RIP } \\
\text { m }^{6} \text { A-Seq } \\
\text { RT-qPCR } \\
\text { WB }\end{array}$ & METTL3 upregulation associates with poor prognosis & 120 patients, cell lines and animal models & Chen M 2017 [55] \\
\hline & $\begin{array}{c}\text { TCGA database } \\
\text { GO and KEGG enrichment } \\
\text { analysis * }\end{array}$ & YTHDF1 upregulation associates with poorer stage and survival & 373 patients & Zhao X 2018 [56] \\
\hline & $\begin{array}{c}\text { MeRIP/RIP } \\
\text { RT-qPCR } \\
\mathrm{m}^{6} \mathrm{~A} \text { Dot Blot/Immunobloting } \\
\text { WB } \\
\text { IHC } \\
\end{array}$ & METTL14 deregulation promotes metastatic spread & 130 patients and animal models & Ma JZ 2017 [57] \\
\hline \multirow{5}{*}{ Breast } & $\mathrm{IHC}$ & $\begin{array}{l}\text { FTO overexpression associates with HER-2 positive } \\
\text { Breast Cancer }\end{array}$ & 79 patients & Tan A 2015 [50] \\
\hline & WB & $\begin{array}{l}\text { Pharmacological inhibition of FTO reduces survival of } \\
\text { chemoresistant Inflammatory Breast Cancer cells }\end{array}$ & Cell lines & Singh B 2016 [51] \\
\hline & $\begin{array}{c}\text { IHC } \\
\text { RT-qPCR } \\
\text { MeRIP/RIP } \\
\text { WB }\end{array}$ & $\begin{array}{l}\text { Hypoxia induces cancer stem cell phenotype by } \\
\text { ALKBH5-mediated } \mathrm{m}^{6} \mathrm{~A} \text {-demethylation }\end{array}$ & Cell lines & $\begin{array}{l}\text { Zhang C 2016 } \\
\text { and } 2016[52,53]\end{array}$ \\
\hline & $\begin{array}{l}\text { Genotyping using custom } \\
\text { Illumina array (iCOGS) }\end{array}$ & SNP in FTP contributes to susceptibility for ER-negative cancer & 6514 patients & Garcia-Closas M 2013 [49] \\
\hline & $\begin{array}{c}\text { MeRIP/RIP } \\
\text { RT-qPCR } \\
\mathrm{m}^{6} \mathrm{~A} \text { Dot Blot/Immunobloting } \\
\text { IHC and IF } \\
\text { WB }\end{array}$ & $\begin{array}{l}\text { Positive feedback loop HBXIP/miR let-7g/METTL3 promotes } \\
\text { cancer progression }\end{array}$ & $\begin{array}{l}24 \text { patients, tissue microarrays ( } 90 \text { breast } \\
\text { cancer tissue samples) and cell lines }\end{array}$ & Cai X 2017 [54] \\
\hline Melanoma & GenoMEL * & FTO associates with higher melanoma risk & 1373 patients & Iles MM 2013 [48] \\
\hline \multirow[t]{2}{*}{ Lung } & $\begin{array}{c}\text { MeRIP/RIP } \\
\mathrm{m}^{6} \mathrm{~A}-\mathrm{Seq} \\
\text { RT-qPCR } \\
\text { WB }\end{array}$ & $\begin{array}{l}\text { METTL3 upregulation increases translation of } \\
\text { oncogenic pathways }\end{array}$ & Cell lines & Lin and Choe 2016 [71] \\
\hline & $\begin{array}{l}\text { RT-qPCR } \\
\text { WB }\end{array}$ & $\begin{array}{l}\text { METTL3 is targeted by miR-33a attenuating malignant } \\
\text { cell proliferation }\end{array}$ & 32 patients and cell lines & Du M 2016 [72] \\
\hline Brain (Glioblastoma) & $\begin{array}{c}\text { MeRIP/RIP } \\
\mathrm{m}^{6} \mathrm{~A}-\mathrm{Seq} \\
\mathrm{m}^{6} \mathrm{~A} \text { Dot Blot/Immunobloting } \\
\text { IF } \\
\text { RT-qPCR }\end{array}$ & $\begin{array}{l}\text { Knockdown of METLL3/METLL14 and FTO inhibition } \\
\text { promotes stem cell renewal and tumorigenesis }\end{array}$ & Cell lines and animal models & Cui Q 2018 [68] \\
\hline
\end{tabular}


Table 1. Cont.

\begin{tabular}{|c|c|c|c|c|}
\hline Tumor Model & Methodology & Outcome & Sample Size & Author (Ref.) \\
\hline & $\begin{array}{c}\mathrm{m}^{6} \mathrm{~A} \text { NorthWestern blot } \\
\text { WB } \\
\text { RT-qPCR } \\
\text { MeRIP/RIP } \\
\text { IHC and IF }\end{array}$ & $\begin{array}{l}\text { METTL3 promotes cancer cells maintenance } \\
\text { and radioresistance }\end{array}$ & 57 patients, cell lines and animal models & Visvanathan A 2017 [70] \\
\hline & $\begin{array}{l}\text { MeRIP/RIP } \\
\mathrm{m}^{6} \mathrm{~A}-\mathrm{Seq} \\
\text { WB } \\
\text { IHC and IF } \\
\text { RT-qPCR }\end{array}$ & $\begin{array}{l}\text { ALKBH5 overexpression promotes self-renewal and } \\
\text { tumorigenesis through the FOXM1 axis }\end{array}$ & 604 patients, cell lines and animal models & Zhang S 2017 [69] \\
\hline \multirow[b]{2}{*}{ Pancreas } & $\begin{array}{l}\text { RT-qPCR } \\
\text { WB }\end{array}$ & METTL3 promotes chemo- and radioresistance & Cell lines & Taketo K 2018 [58] \\
\hline & $\begin{array}{l}\text { RT-qPCR } \\
\text { IHC } \\
\text { WB }\end{array}$ & YTHDF2 is upregulated in cancer and regulates EMT & Cell lines & Chen J, 2017 [59] \\
\hline Biliary tract & $\begin{array}{c}\text { cDNA microarray } \\
\text { RT-qPCR } \\
\text { WB } \\
\text { IHC }\end{array}$ & WTAP promotes migration and invasion & 27 patients, cell lines and animal models & Jo HJ, 2013 [60] \\
\hline Stomach & $\begin{array}{l}\text { IHC } \\
\text { RT-qPCR } \\
\text { WB }\end{array}$ & $\begin{array}{l}\text { FTO overexpression associates with poor prognosis and } \\
\text { promotes malignant features }\end{array}$ & 128 patients and cell lines & Xu D 2017 [64] \\
\hline \multirow[b]{2}{*}{ Cervix } & $\begin{array}{c}\mathrm{m}^{6} \mathrm{~A} \text { Dot Blot/Immunobloting } \\
\text { RT-qPCR } \\
\text { WB }\end{array}$ & $\begin{array}{l}\text { Lower } \mathrm{m}^{6} \mathrm{~A} \text { levels associate with poor prognosis and } \\
\text { malignant features }\end{array}$ & 286 patients, cell lines and animal models & Wang X 2017 [65] \\
\hline & $\begin{array}{c}\text { IHC } \\
\text { RT-qPCR } \\
\text { WB } \\
\text { MeRIP/RIP }\end{array}$ & FTO overexpression leads to chemo- and radioresistance & 30 patients, cell lines and animal models & Zhou S and Bai ZL 2018 [66] \\
\hline Endometrium & $\begin{array}{c}\mathrm{m}^{6} \mathrm{~A}-\mathrm{seq} \\
\mathrm{m}^{6} \mathrm{~A}-\mathrm{IP} \\
\text { RT-qPCR } \\
\text { IHC } \\
\text { WB }\end{array}$ & $\begin{array}{l}\text { METTL14 mutation and METTL3 downregulation leads to } \\
\text { decreased } \mathrm{m}^{6} \mathrm{~A} \text { amount and promotes tumorigenesis by } \\
\text { activating AKT signaling }\end{array}$ & 38 patients, cell lines and animal models & Liu J, 2018 [67] \\
\hline \multirow{2}{*}{ Colorectum } & $\begin{array}{l}\text { IHC } \\
\text { RT-qPCR } \\
\text { WB }\end{array}$ & YTHDF1 overexpression associates with poor prognosis & 63 patients, cell lines and animal models & $\begin{array}{l}\text { Nishizawa Y and } \\
\text { Kono M } 2017 \text { [61] }\end{array}$ \\
\hline & $\begin{array}{l}\text { IHC } \\
\text { RT-qPCR } \\
\text { WB }\end{array}$ & $\begin{array}{l}\text { YTHDC2 overexpression promotes metastases by } \\
\text { upregulating HIF- } 1 \alpha\end{array}$ & 72 patients and cell lines & Tanabe A 2016 [62] \\
\hline
\end{tabular}


Table 1. Cont

\begin{tabular}{|c|c|c|c|c|}
\hline Tumor Model & Methodology & Outcome & Sample Size & Author (Ref.) \\
\hline \multirow{5}{*}{ Leukemia } & TCGA database * & $\begin{array}{l}\text { Mutations and CNVs in } \mathrm{m}^{6} \mathrm{~A}-\text {-related genes associate with TP53 } \\
\text { mutations and poor prognosis in AML patients }\end{array}$ & 191 patients & Kwok CT 2017 [73] \\
\hline & $\begin{array}{c}\text { MeRIP/RIP/ChIP } \\
\text { ChIP-seq } \\
\text { WB } \\
\text { RT-qPCR } \\
\text { Flow cytometry }\end{array}$ & METTL3 maintains leukemic state & Cell lines and animal models & $\begin{array}{l}\text { Barbieri I and } \\
\text { Tzelepis K } 2017 \text { [75] }\end{array}$ \\
\hline & $\begin{array}{c}\mathrm{m}^{6} \mathrm{~A}-\mathrm{seq} / \mathrm{RNA} \text {-seq } \\
\text { CLIP } \\
\text { ChIP } \\
\text { WB } \\
\text { RT-qPCR } \\
\text { Flow cytometry }\end{array}$ & $\begin{array}{l}\text { METTL14 promotes leukemogenesis and inhibits hematopoietic } \\
\text { stem cell differentiation }\end{array}$ & Cell lines and animal models & Weng H 2018 [74] \\
\hline & $\begin{array}{c}\mathrm{m}^{6} \mathrm{~A}-\mathrm{seq} / \mathrm{RNA} \text {-seq } \\
\text { ChIP } \\
\text { WB } \\
\text { RT-qPCR } \\
\mathrm{m}^{6} \mathrm{~A} \text { Dot Blot/Immunobloting } \\
\text { Flow cytometry }\end{array}$ & $\begin{array}{l}\text { FTO promotes leukemogenesis by regulating the } \\
\text { ASB2/RARA axis }\end{array}$ & 100 patients, cell lines and animal models & Li Z 2017 [80] \\
\hline & $\begin{array}{c}\text { WB } \\
\text { IP } \\
\text { RNA-seq }\end{array}$ & $\begin{array}{l}\text { WTAP promotes leukemic cells proliferation and } \\
\text { blocks differentiation }\end{array}$ & 511 patients, cell lines and animal models & Bansal H 2014 [77] \\
\hline
\end{tabular}

* In silico analysis only. Abbreviations: cDNA-Complementary DNA; ChIP—Chromatin immunoprecipitation; ChIP-seq-Chromatin immunoprecipitation sequencing; CLIP-Cross-linking and RNA Immunoprecipitation; EMT-Epithelial-to-mesenchymal transition; IF-Immunofluorescence; IHC-Immunohistochemistry; $\mathrm{m}^{6} \mathrm{~A}-\mathrm{Seq}-\mathrm{m}^{6} \mathrm{~A}$ Sequencing; MeRIP—Methylated $\left(\mathrm{m}^{6} \mathrm{~A}\right)$ RNA Immunoprecipitation; RIP—RNA immunoprecipitation; RNA-seq—RNA sequencing; RT-qPCR—Real-time quantitative Polymerase Chain Reaction; TCGA-The Cancer Genome Atlas; WB-Western blot. 


\section{3. $\mathrm{m}^{6} \mathrm{~A}$ Modifications in Urological Tumors: Analysis of The Cancer Genome Atlas Database}

Although RNA modifications have been analyzed in several tumor models in recent years, little attention has been paid to urological cancer. One of our main research goals is to uncover and characterize new epigenetic modifiers in urological malignancies, to be applied in diagnosis, prognosis and disease monitoring. In this line, we performed an in silico analysis of the publicly available The Cancer Genome Atlas (TCGA) database regarding $\mathrm{m}^{6} \mathrm{~A}$-related proteins (writers, erasers and readers) in the four main urological cancers: bladder (BlCa), kidney (KCa), prostate (PCa) and testicular cancer. For that purpose, the online resource cBioPortal for Cancer Genomics [83] was used, with the user-defined entry gene set "METTL3, METTL14, METTL4, METTL16, WTAP, VIRMA, RBM15, RBM15B, FTO, ALKBH5, YTHDF1, YTHDF2, YTHDF3, YTHDC1, YTHDC2, EIF3A, HNRNPC and HNRNPA2B1". Statistical analysis with the available data was performed with Microsoft Excel 2016, (Microsoft, Redmond, Washington, USA), GraphPad Prism 6 (Prism, San Diego, California, USA) and IBM SPSS Statistics v.24 (Armonk, NY, USA). Distribution of continuous variables between groups was compared using the nonparametric Mann-Whitney test. Correlations between continuous variables were assessed with Spearman's non-parametric correlation test. Co-occurrence/mutual exclusivity of alterations in pairs of genes was estimated with odds ratio (OR). Biomarker performance was assessed through receiver operating characteristics (ROC) curve construction. In brief, for each transcript, an ROC curve was constructed plotting sensitivity (true positive) against 1-specificity (false positive). A cut-off was established by ROC curve analysis (sensitivity + (1-specificity)), to maximize both sensitivity and specificity. In addition, area under the curve (AUC) and biomarker performance parameters, including sensitivity, specificity, positive predictive value (PPV), negative predictive value (NPV) and accuracy, were ascertained. Survival curves were plotted using the Kaplan-Meier method and $\log$ rank test was used for survival analysis. A $p$-value equal or inferior to 0.05 was considered statistically significant.

\subsection{Prostate Cancer}

PCa is a major public health concern in male gender mainly due to the growth and aging of the global population [84]. It is a highly prevalent malignancy, being the second most common cancer and the fifth leading cause of death from cancer in men, mostly due to aggressive and metastatic disease [85]. This neoplasia is usually clinically silent until extra-prostatic invasion or metastization occur, being a complex and heterogeneous disease, ranging from clinically indolent to highly aggressive $[86,87]$. At its earliest stages, PCa is sensitive to androgen-deprivation therapy, which is the mainstay treatment for advanced disease. Nevertheless, patients eventually develop castration-resistance and progress to lethal PCa [88].

Concerning patient management, clinicians face three major challenges: to distinguish PCa from benign prostatic hyperplasia and other cancer mimickers; to discriminate indolent from aggressive disease; and to foresee patients that will undergo disease progression and develop metastatic disease [89]. Epigenetic alterations are a common trait in PCa and are involved in disease onset and progression. Despite their exact roles are still not fully understood, the fact that they occur at a higher rate and in an earlier point than mutations makes them very attractive biomarkers for diagnosis, prognosis and follow-up purposes [90].

The TCGA database for PCa includes 499 samples from 498 patients, with a median age at diagnosis of 61 years. Patients were American Joint Committee on Cancer (AJCC) stages II, III and IV in 187/490 (38.2\%), 293/490 (59.8\%) and 10/490 (2.0\%) cases. Regarding Gleason score and respective grade groups (GG), patients were classified from GG 1 to 5 (GG1 $=8.8 \%$, GG2 $=29.4 \%$, GG3 $=20.5 \%$, GG4 $=12.9 \%$ and GG5 $=28.4 \%$ ). Ten patients died and 58 experienced disease recurrence/progression, resulting in an overall survival (OS) and disease-free survival (DFS) at 10 years of $68 \%$ and $53 \%$, respectively.

Overall, the 18-gene list was found to be altered in 307/499 samples (61.5\%), mainly by mRNA upregulation $(n=111,22.2 \%)$. mRNA downregulation also occurred in 54 cases $(10.8 \%)$, and 
multiple alterations were depicted in 88 cases (17.6\%). Individual mutations, amplifications, deep deletions, protein upregulations or protein downregulations were seldomly observed $(n=7,1.4 \%$; $n=7,1.4 \% ; n=34,6.8 \% ; n=2,0.4 \%$ and $n=4,0.8 \%$, respectively).

Deregulation of VIRMA, a component of the methylation complex, and of the readers YTHDF3 and YTHDC2 are of particular interest, constituting the most commonly altered genes in the pathway $(18 \%, 13 \%$ and $11 \%$ of the samples, respectively). The remainder genes analyzed depicted alterations in less than $10 \%$ of samples. In addition, no mutations are described for YTHDF3 and YTHDC2 that may explain the deregulation, and only three samples disclosed a missense mutation in VIRMA. There was also a modest correlation between VIRMA and YTHDF3 mRNA expression in PCa samples (correlation coefficient: 0.62 ).

Analysis of alterations in the various pairs of genes showed two gene pairs with significant co-occurrent alterations. The strongest associations, with Bonferroni correction, included VIRMA and YTHDF3 $(\log$ OR $>2$ and $p<0.001)$.

Regarding clinicopathologic correlates, VIRMA and YTHDF3 mRNA expression levels were significantly higher in stage III/IV compared to stage II tumors ( $p \leq 0.0001$ and $p=0.0454$, respectively). In the same line, higher VIRMA and YTHDF3 transcript levels associated with higher GG (GG2-5 vs. GG1, $p=0.0198$ and $p=0.0215$, respectively), again suggesting higher expression of these players in more aggressive diseases. None of the genes tested impacted on overall survival (OS) or disease-free survival (DFS).

Although still largely unexplored, there is already a study (using both cell lines and human tissues from 35 patients) reporting $\mathrm{m}^{6} \mathrm{~A}$ alterations in PCa. Specifically, the authors report that YTHDF2, an $\mathrm{m}^{6} \mathrm{~A}$ reader, is regulated by $\mathrm{miR}-493-3 \mathrm{p}$ and its upregulation is involved in the $\mathrm{m}^{6} \mathrm{~A}$ modification and malignant progression [91].

\subsection{Testicular Cancer}

Testicular germ cell tumors (TGCTs) comprise more than 95\% of all testicular neoplasms, and are grouped into two major families according to the most recent World Health Organization (WHO) classification: the germ-cell neoplasia in situ (GCNIS)-related tumors (the most frequent, which include seminomas (SEs) and non-seminomatous Tumors (NSTs), two subgroups with very distinct behavior and clinical impact), and the GCNIS-unrelated ones [92].

Despite representing only $1 \%$ of male cancer worldwide, they constitute the most common cancer afflicting Caucasian men between 15-44 years old, with Western lifestyle contributing to a rising incidence worldwide. They also exhibit outstanding cure rates and a dropping mortality trend in response to multimodal treatments. However, many issues are left unresolved and deserve our attention, namely the substantial proportion of patients with disseminated disease that relapse with poor prognosis, the emergence of cisplatin resistance and the considerable morbidity induced by chemo- and radiotherapy in such young patients with long survival expectancy [85,93-95].

Testicular germ cell tumors are remarkably heterogeneous (reflecting the complexity of this tumor model) [96] but mainly share a unifying cytogenetic background. In this line, it is only natural that various Epi-phenomena might play a fundamental role in these neoplasms. Therefore, the study of new Epi-markers might aid in tumor subtype discrimination, prognosis assessment and disease monitoring, as no accurate validated biomarkers exist for these purposes. In addition, the manipulation of these Epi-markers might provide ways of uncovering therapies with improved antitumor activity, less toxicity and that may overcome cisplatin resistance [97-101].

The database for TGCTs includes 156 samples from 150 patients, 65 SEs, 71 NSTs and a third category of tumors regarded as Embryonal Carcinoma (EC), composed of 20 samples. This way, the total amount of NSTs in the cohort is 91 . Median age at diagnosis is 31 years. Patients were AJCC stages I, II and III in 100/126 (79.4\%), 12/126 (9.5\%) and 14/126 (11.1\%) cases. According to the International Germ Cell Consensus Collaborative Group (IGCCCG) for metastatic disease [102], 32/43 (74.4\%), 9/43 (20.9\%) and 2/43 (4.7\%) patients were in prognostic groups "Good", "Intermediate" and "Poor". 
Three patients died and 33 experienced disease recurrence/progression, resulting in an OS and DFS at five years of $98 \%$ and $76 \%$, respectively.

Overall, the 18-gene list was found altered in 134/156 samples (85.9\%), mainly by mRNA upregulation $(n=94,70.2 \%)$. mRNA downregulation occurred in 15 cases $(11.2 \%)$, and multiple alterations were depicted in 19 cases (14.2\%). Like in PCa, individual mutations, amplifications, deep deletions or protein downregulations were seldomly observed $(n=2,1.5 \% ; n=1,0.7 \% ; n=2,1.5 \%$; and $n=1,0.7 \%$, respectively).

Paralleling our analysis on PCa, deregulation of VIRMA and the reader YTHDF3 is particularly interesting in TGCTs as well, being the two most commonly altered genes in the pathway (52\% and $48 \%$ of samples, respectively). Following these two major deregulated genes, the reader HNRNPA2B1 and the writer METTL3 were also altered in 13\% and 10\% of the samples, respectively. The remaining genes analyzed disclosed alterations in less than 10\% of samples. VIRMA and YTHDF3 are differently deregulated in SEs and NSTs (depicting alterations in $80 \%$ and $72 \%$ of SEs and in only $31 \%$ and $31 \%$ of NSTs, respectively), again mainly by mRNA upregulation. In addition, no mutations have been described for YTHDF3 that can explain its deregulation, and only one sample disclosed a missense mutation in VIRMA. There was also a strong correlation between VIRMA and YTHDF3 mRNA expression in TGCT samples (correlation coefficient 0.77 ).

Analysis of alterations in the various pairs of genes identified 10 gene pairs with significant co-occurrent alterations. The strongest associations included VIRMA + YTHDF3, YTHDC2 + EIF3A and METTL14 + YTHDC2 ( $\log$ OR $>3$ and $p<0.001$ for all). However, the only one significant applying Bonferroni correction was precisely the VIRMA + YTHDF3 pair (log OR $>3, p$-value $<0.001)$. Four gene pairs showed significant mutual exclusivity alterations, the strongest being YTHDF2 + YTHDF3 (log OR $<-3, p=0.002)$, VIRMA + HNRNPC $(\log$ OR $<-3, p=0.011)$ and YTHDF3 + HNRNPC $(\log$ OR $<-3$, $p=0.018)$. However, none was significant after Bonferroni correction for multiple comparisons.

Regarding subtype discrimination, mRNA expression levels of VIRMA and YTHDF3, but also the writer METTL4, the eraser ALKBH5 and the reader YTHDC1, were significantly higher in SEs compared to NSTs ( $p<0.0001$ for all). On the contrary, the writer METTL14 was significantly downregulated in SEs vs. NSTs $(p<0.0001)$. Of these genes, the best discriminative power assessed by ROC curve analysis was METTL4 (AUC $=0.91$ ), followed by VIRMA (AUC $=0.83$ ). Using the mRNA expression level that maximizes both sensitivity and specificity (228.04925) as cutoff, METTL4 discriminated between SEs and NSTs with $92.3 \%$ sensitivity, $82.4 \%$ specificity, $78.9 \%$ positive predictive value, and $93.8 \%$ negative predictive value, resulting in overall accuracy of $86.5 \%$. Remarkably, METTL4 outperforms the serological markers commonly used in clinical practice ( $\alpha$-fetoprotein, subunit $\beta$ of the human chorionic gonadotropin and lactate dehydrogenase) [95].

Furthermore, mRNA expression levels of METTL4, VIRMA and YTHDF3 were also significantly higher in stage I compared to stage II/III TGCTs ( $p=0.0234, p=0.0065$ and $p=0.0165$, respectively). Regarding survival analysis, the only genes with impact on survival were METTL4 (cases with alterations showing worse DFS, $p=0.0249$ ), WTAP (cases with alterations showing worse DFS, $p=0.0402$ ) and YTHDF1 (cases with alterations showing worse OS, $p=0.0440$ ).

\subsection{Kidney Cancer}

Kidney cancer is the 14th most common malignancy worldwide and the 8 th most prevalent cancer in Europe representing 3.5\% of all adult malignancies. It is the most lethal among common urological cancers and, in 2012, there were 143,406 deaths attributable to this malignancy worldwide. Furthermore, incidence varies by gender, with men having twice the risk of women [85,103]. Due to its retroperitoneal topography, many renal masses remain asymptomatic until late stages. However, widespread use and improvement of imaging methods led to increased incidental detection of small renal masses, emphasizing the need for accurate discrimination among KCa subtypes, specifically between those which will be more aggressive and develop metastases and those that will have a more indolent growth and may be managed more conservatively [104]. 
According to the current World Health Organization (WHO) 2016 classification, malignant tumors are classified into three most common subtypes: clear cell renal cell carcinoma (ccRCC) $(65-70 \%)$, the most common and aggressive phenotype; papillary renal cell carcinoma (pRCC) (15-20\%), which has two variants, types 1 and 2; and chromophobe renal cell carcinoma (chRCC) (5-10\%), the least aggressive of these [92].

The database for renal cell carcinoma includes 897 samples from 895 patients (67\% male), from which 538/897 (60\%) are ccRCC, 66/897 (7\%) are chRCC and 293/897 (33\%) are pRCC. Median patient age at diagnosis was 60 years. Patients were AJCC stages I, II, III and IV in 462/858 (54\%), 102/858 $(12 \%), 190 / 858$ (22\%) and 104/858 (12\%) cases, respectively. During follow-up, 227 patients died and 189 experienced disease recurrence/progression, resulting in an OS and DFS at five years of $69 \%$ and $72 \%$, respectively.

Overall, the 18-gene list was altered in 585/883 samples (66\%). Specifically, by tumor subtype, the most commonly altered genes were: YTHDC2 (21\%) and RBM15B (14\%) in ccRCC, mostly due to mRNA upregulation (26.4\%); VIRMA (17\%) and HNRNPA2B1 $(17 \%)$ in chRCC, mostly due to mRNA downregulation (26.4\%); and METTL16 (19\%), YTHDF1 (19\%) and RBM15B (14\%) in pRCC, mostly due to mRNA upregulation (26.4\%).

There were two gene pairs with significant co-occurrent alterations, after Bonferroni correction, including VIRMA + YTHDF3 and RBM15B + YTHDC2 (both with $\log$ OR $>3$ and $p<0.001$ ). No significant gene pairs with mutually exclusive alterations were found.

VIRMA, RBM15B and YTHDC2 mRNA expression levels discriminated among ccRCC, chRCC and pRCC; transcript levels of VIRMA and YTHDC2 were lower in chRCC $(p<0.0001$ for both) and in pRCC $(p<0.0001$ and $p=0.0006$, respectively) compared to ccRCCC. Contrarily, RBM15B was significantly upregulated in chRCC $(p<0.0001)$ and in pRCC $(p<0.0001)$ compared to ccRCC. Furthermore, RBM15B and YTHDC2 higher expression levels associated with advanced AJCC tumor stage (Stages II-IV vs. Stage I, $p=0.0361$ and $p=0.0045$, respectively). Regarding survival analysis, the only genes with impact on survival were VIRMA and YTHDC2 in ChRCC in both OS (mRNA upregulation conferring worse OS, $p=0.0280$ and $p=0.0497$, respectively) and DFS (mRNA upregulation conferring worse DFS, $p=0.0203$ and $p=00152$, respectively), and RBM15B in pRCC only in DFS (mRNA downregulation conferring worse DFS, $p=0.0082$ ).

Although there is substantial lack of information regarding $\mathrm{m}^{6} \mathrm{~A}$ alterations in $\mathrm{KCa}, \mathrm{Li}$ and Tang et al. reported that higher expression of METTL3 might indicate better survival among RCC patients. Their study, which included both cell lines and human tissues from 145 patients (127 ccRCC and 18 designated as "others"), showed that this $\mathrm{m}^{6} \mathrm{~A}$ writer might act as a tumor suppressor and may have impact on tumorigenesis and survival of KCa patients [105].

\subsection{Bladder Cancer}

Bladder cancer is the 9th most common cancer worldwide, with an estimated 430,000 new cases diagnosed in 2012. It is more prevalent in males (3/4 of all BlCa cases), representing the 6 th most incident neoplasm in this group. Importantly, it is an important health issue, as recent trends follow tobacco smoking prevalence and because it was responsible for 165,000 deaths in 2012 (75\% of which in men) [106,107].

The major histological type of $\mathrm{BlCa}$ is urothelial carcinoma. There are two major clinical, pathological and molecular forms of the disease: the non-papillary muscle-invasive tumors (with carcinoma in situ as the major precursor, being the most aggressive, more prone to progress and metastasize $-25 \%$ of newly diagnosed cases) and the papillary non-muscle-invasive ones (with papillary urothelial lesions as precursors, being mainly characterized by multiple local recurrences, associated morbidity and, finally, increased risk of muscle-invasion over time- $75 \%$ of newly diagnosed cases) [108].

The database for bladder urothelial carcinoma comprises muscle-invasive carcinoma only and includes 413 samples from 412 patients (73.5\% male), 273/406 (67.2\%) originating from the 
non-papillary pathway and $133 / 406(32.8 \%)$ from the papillary pathway. Median patient age at diagnosis was 69 years and 387/408 (94.9\%) tumors were high grade. Patients were AJCC stages I, II, III and IV in 2/ 409 (0.5\%), 131/409 (32.0\%), 141/409 (34.5\%) and 135/409 (33.0\%) cases. During follow-up, 181 patients died and 143 experienced disease recurrence/progression, resulting in OS and DFS at 5 years of $42 \%$ and $41 \%$, respectively.

Overall, the 18-gene list was altered in 329/413 samples ( $80.0 \%)$, mainly by mRNA upregulation $(n=134,40.7 \%)$ or by multiple alterations $(n=131,39.8 \%)$. mRNA downregulation, mutations, amplifications, deep deletions and proteins downregulations were depicted in $20(6.1 \%), 15(4.6 \%)$, $12(3.7 \%), 10(3.0 \%)$ and $7(2.1 \%)$ cases, respectively.

Like TGCTs, the most commonly deregulated gene was VIRMA (29\% of samples), mainly by upregulation. Other frequently deregulated genes were YTHDF1 (27\%), METTL4 (21\%), YTHDF3 $(14 \%)$ and RBM15 (13\%). VIRMA was also deregulated in 33\% of non-papillary tumors, but only in $20 \%$ of papillary tumors. The rate of somatic mutations in these genes was only $0.5 \%, 0.5 \%$ and $0.7 \%$ for YTHDF1, METTL4, and YTHDF3, respectively; VIRMA and RBM15 mutations were found in 9 $(2.2 \%)$ and $12(2.9 \%)$ cases. There was a moderate correlation between expression levels of VIRMA and YTHDF3 (correlation coefficient 0.57) and METTL14 (correlation coefficient 0.40).

There were eight gene pairs with significant co-occurrent alterations; after Bonferroni correction, the strongest ones included METTL14 + YTHDC1 ( $\log$ OR 2.308, $p=0.042)$ and METTL3 + HNRNPC $(\log$ OR 2.260, $p<0.001)$. Like in TGCTs, VIRMA + YTHDF3 also tended to co-occur $(\log$ OR 1.915, $p<0.001)$. No significant gene pairs with mutual exclusive alterations were found.

High grade tumors showed significantly higher mRNA expression of VIRMA, METTL4 and YTHDF3 compared to low grade tumors $(p=0.003, p<0.001$ and $p=0.041$, respectively), but the discriminative power was limited, the best disclosed by METTL4 (AUC 0.80). METTL4 and YTHDF1 mRNA expression levels did not, however, discriminate between papillary and non-papillary derived tumors $(p=0.1622$ and $p=0.4321$, respectively), but VIRMA was significantly upregulated in non-papillary tumors $(p=0.022)$, contrarily to YTHDC1 which was upregulated in papillary tumors $(p=0.0038)$. Nonetheless, the discriminative power was poor (AUC 0.59 for both).

YTHDC1 was upregulated in stage I/II compared to stage III/IV disease $(p=0.0089)$. Regarding survival analysis, the only gene with impact on survival was WTAP (cases with alterations showing better OS, $p=0.0261$ ). A summary of these findings is depicted in Table 2 and illustrated in Figure 2.

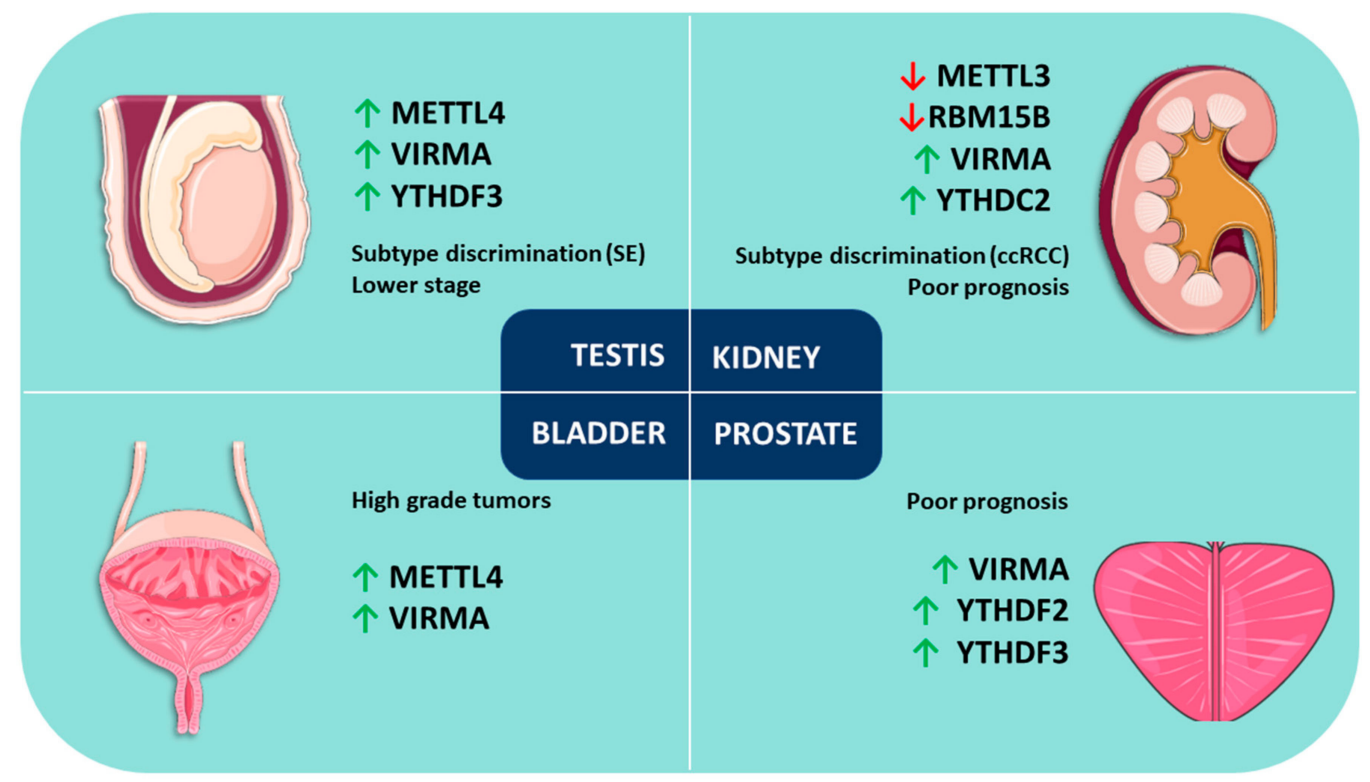

Figure 2. Review of $\mathrm{m}^{6} \mathrm{~A}$ modification and related proteins in urological malignancies. Upward arrows mean "upregulation", and downward arrows mean "downregulation." 
Table 2. Most relevant findings of in silico analysis of TCGA database regarding $\mathrm{m}^{6} \mathrm{~A}$-related proteins in urological cancers.

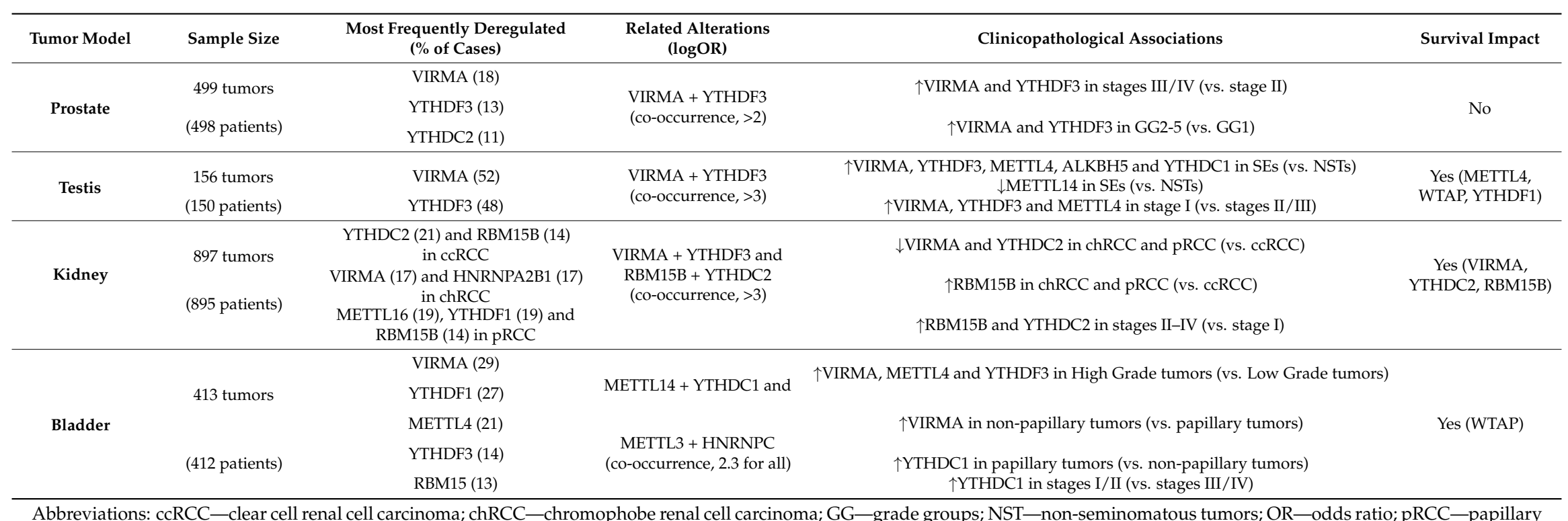

renal cell carcinoma; SE-seminoma. 


\section{Discussion}

In PCa, higher expression levels of VIRMA and YTHDF3 appear to be associated with advanced disease. The positive correlation between VIRMA and the reader YTHDF3 suggests cooperation for the establishment of $\mathrm{m}^{6} \mathrm{~A}$ modification in these tumors. YTHDF2 expression also has an impact on disease progression as shown by Li and Meng et al. [91].

On the other hand, in TGCTs, expression levels of METTL4 and VIRMA seem promising biomarkers for discrimination between SEs and NSTs. In this tumor model, a positive strong correlation between VIRMA and the reader YTHDF3 was also observed, supporting again a cooperation between these two players for establishing $\mathrm{m}^{6} \mathrm{~A}$ modification in urologic tumors. METTL4 expression had also an impact on DFS and associated with disease stage, as did VIRMA and YTHDF3 expression.

In KCa, VIRMA, RBM15B and YTHDC2 expression levels are auspicious biomarkers for discrimination among RCC subtypes, having impact on OS and DFS. Specifically, RBM15B and YTHDC2 associate with the advanced disease stage. Moreover, METTL3 plays a tumor suppressor role in this malignancy possibly acting as a novel marker for kidney tumorigenesis, as suggested by $\mathrm{Li}$ and Tang et al. [105].

Finally, in BICa, VIRMA and METTL4 seem to be the most useful markers, as they are amongst the most commonly deregulated and they are significantly upregulated in high grade tumors. VIRMA was significantly upregulated in non-papillary tumors, but discrimination of the two major BlCa pathways using these markers remains a challenge.

Overall, regarding non-urological malignancies, upregulation of writers and/or writer-related players, tend to associate with more aggressive cancer features (poor prognosis, invasiveness, metastases and even treatment resistance). Mechanistically, this seems to imply that higher amounts of $\mathrm{m}^{6} \mathrm{~A}$ modification in target RNAs might result in the development of cancer-prone features. Urological cancers tend to follow the same pattern, with upregulation of methylating enzymes associated with higher tumor grade and stage. The finding seems to contrast with the idea that $\mathrm{m}^{6} \mathrm{~A}$ introduction is necessary for differentiation and that decreased $\mathrm{m}^{6} \mathrm{~A}$ amount results in resistance to differentiation [29]. Nonetheless, exceptions exist both in urological and non-urological cancers. For instance, in TGCTs, higher VIRMA expression was found to be associated with low disease stage; in addition, in $\mathrm{KCa}$, RBM15B overexpression (an eraser) associated with advanced disease at diagnosis, whereas the writer METTL3 was reported to act as a tumor suppressor. Ultimately, this might be interpreted in several ways: either the reader dictates the overall final destination of the target RNA (which can vary from degradation to increased translation), or $\mathrm{m}^{6} \mathrm{~A}$ target RNAs may function as tumor suppressors or oncogenes. Overall, one has to take into account tumor subtype, relative expression of writers, erasers and readers, as well as the exact transcripts that are $\mathrm{m}^{6} \mathrm{~A}$-targeted.

Considering the ensemble of urological cancers, VIRMA upregulation stands as a common and shared trait, although in a variable proportion of cases. Considering the dissimilarity of age groups affected, as well as of risk factors, this is an intriguing observation. Nevertheless, it emphasizes the relevance of epitranscriptomics, and of $\mathrm{m}^{6} \mathrm{~A}$ alteration in particular, in the genesis and progression of urological cancers.

Author Contributions: Conception and Design: J.L. and D.B.-S.; Revision and Editing: R.H. and C.J.

Funding: This research was funded by Research Center-Portuguese Oncology Institute of Porto (CI-IPOFB-GEBC-2018) and FCT (POCI-01-0145-FEDER-29043). This work was carried out in the framework of the European COST Action EPITRAN CA16120. J.L. is supported by an FCT-Fundação para a Ciência e Tecnologia-fellowship (SFRH/BD/132751/2017). D.B.-S is a research fellow from CI-IPOP (BI-GEBC2018/UID/DTP/00776/POCI-01-0145-FEDER-006868).

Conflicts of Interest: The authors declare no conflict of interest. 


\section{References}

1. Bheda, P.; Schneider, R. Epigenetics reloaded: The single-cell revolution. Trends Cell Biol. 2014, 24, 712-723. [CrossRef] [PubMed]

2. He, C. Grand challenge commentary: RNA epigenetics? Nat. Chem. Biol. 2010, 6, 863-865. [CrossRef] [PubMed]

3. Batista, P.J. The RNA modification N(6)-methyladenosine and its implications in human disease. Genom. Proteom. Bioinform. 2017, 15, 154-163. [CrossRef] [PubMed]

4. Zhang, Z.; Park, E.; Lin, L.; Xing, Y. A panoramic view of RNA modifications: Exploring new frontiers. Genome Biol. 2018, 19, 11. [CrossRef] [PubMed]

5. Boccaletto, P.; Machnicka, M.A.; Purta, E.; Piatkowski, P.; Baginski, B.; Wirecki, T.K.; De Crecy-Lagard, V.; Ross, R.; Limbach, P.A.; Kotter, A.; et al. MODOMICS: A database of RNA modification pathways. 2017 update. Nucleic Acids Res. 2018, 46, D303-D307. [CrossRef] [PubMed]

6. Davalos, V.; Blanco, S.; Esteller, M. SnapShot: Messenger RNA modifications. Cell 2018, 174, 498-498.e1. [CrossRef] [PubMed]

7. Liu, J.; Jia, G. Methylation modifications in eukaryotic messenger RNA. J. Genet. Genom. 2014, 41, 21-33. [CrossRef] [PubMed]

8. Jacob, R.; Zander, S.; Gutschner, T. The dark side of the epitranscriptome: Chemical modifications in long non-coding RNAs. Int. J. Mol. Sci. 2017, 18, 2387. [CrossRef] [PubMed]

9. Frye, M.; Jaffrey, S.R.; Pan, T.; Rechavi, G.; Suzuki, T. RNA modifications: What have we learned and where are we headed? Nat. Rev. Genet. 2016, 17, 365-372. [CrossRef] [PubMed]

10. Desrosiers, R.; Friderici, K.; Rottman, F. Identification of methylated nucleosides in messenger RNA from Novikoff hepatoma cells. Proc. Natl. Acad. Sci. USA 1974, 71, 3971-3975. [CrossRef] [PubMed]

11. Xiong, X.; Yi, C.; Peng, J. Epitranscriptomics: Toward a better understanding of RNA modifications. Genom. Proteom. Bioinform. 2017, 15, 147-153. [CrossRef] [PubMed]

12. Meyer, K.D.; Saletore, Y.; Zumbo, P.; Elemento, O.; Mason, C.E.; Jaffrey, S.R. Comprehensive analysis of mRNA methylation reveals enrichment in 3' UTRs and near stop codons. Cell 2012, 149, 1635-1646. [CrossRef] [PubMed]

13. Pan, T. N6-methyl-adenosine modification in messenger and long non-coding RNA. Trends Biochem. Sci. 2013, 38, 204-209. [CrossRef] [PubMed]

14. Liu, N.; Pan, T. N6-methyladenosine-encoded epitranscriptomics. Nat. Struct. Mol. Biol. 2016, $23,98-102$. [CrossRef] [PubMed]

15. Meyer, K.D.; Jaffrey, S.R. The dynamic epitranscriptome: N6-methyladenosine and gene expression control. Nat. Rev. Mol. Cell Biol. 2014, 15, 313-326. [CrossRef] [PubMed]

16. Maity, A.; Das, B. N6-methyladenosine modification in mRNA: Machinery, function and implications for health and diseases. FEBS J. 2016, 283, 1607-1630. [CrossRef] [PubMed]

17. Li, X.; Xiong, X.; Yi, C. Epitranscriptome sequencing technologies: Decoding RNA modifications. Nat. Methods 2016, 14, 23-31. [CrossRef] [PubMed]

18. Imanishi, M.; Tsuji, S.; Suda, A.; Futaki, S. Detection of N(6)-methyladenosine based on the methyl-sensitivity of MazF RNA endonuclease. Chem. Commun. (Camb.) 2017, 53, 12930-12933. [CrossRef] [PubMed]

19. Schaefer, M.; Kapoor, U.; Jantsch, M.F. Understanding RNA modifications: The promises and technological bottlenecks of the 'epitranscriptome'. Open Biol. 2017, 7, 170077. [CrossRef] [PubMed]

20. Patil, D.P.; Pickering, B.F.; Jaffrey, S.R. Reading m(6)A in the transcriptome: M(6)A-binding proteins. Trends Cell Biol. 2018, 28, 113-127. [CrossRef] [PubMed]

21. Visvanathan, A.; Somasundaram, K. mRNA traffic control reviewed: N6-methyladenosine $(\mathrm{m}(6) \mathrm{A})$ takes the driver's seat. Bioessays 2018, 40. [CrossRef] [PubMed]

22. Meyer, K.D.; Jaffrey, S.R. Rethinking m(6)A readers, writers, and erasers. Annu. Rev. Cell Dev. Biol. 2017, 33, 319-342. [CrossRef] [PubMed]

23. Wu, B.; Li, L.; Huang, Y.; Ma, J.; Min, J. Readers, writers and erasers of N(6)-methylated adenosine modification. Curr. Opin. Struct. Biol. 2017, 47, 67-76. [CrossRef] [PubMed]

24. Huang, J.; Yin, P. Structural Insights into N(6)-methyladenosine (m(6)A) modification in the transcriptome. Genom. Proteom. Bioinform. 2018, 16, 85-98. [CrossRef] [PubMed] 
25. Yang, D.; Qiao, J.; Wang, G.; Lan, Y.; Li, G.; Guo, X.; Xi, J.; Ye, D.; Zhu, S.; Chen, W.; et al. N6-Methyladenosine modification of lincRNA 1281 is critically required for mESC differentiation potential. Nucleic Acids Res. 2018, 46, 3906-3920. [CrossRef] [PubMed]

26. Bertero, A.; Brown, S.; Madrigal, P.; Osnato, A.; Ortmann, D.; Yiangou, L.; Kadiwala, J.; Hubner, N.C.; De Los Mozos, I.R.; Sadee, C.; et al. The SMAD2/3 interactome reveals that TGFbeta controls m(6)A mRNA methylation in pluripotency. Nature 2018, 555, 256-259. [CrossRef] [PubMed]

27. Weng, Y.L.; Wang, X.; An, R.; Cassin, J.; Vissers, C.; Liu, Y.; Liu, Y.; Xu, T.; Wang, X.; Wong, S.Z.H.; et al. Epitranscriptomic $\mathrm{m}(6) \mathrm{A}$ regulation of axon regeneration in the adult mammalian nervous system. Neuron 2018, 97, 313-325.e6. [CrossRef] [PubMed]

28. Tong, J.; Cao, G.; Zhang, T.; Sefik, E.; Amezcua Vesely, M.C.; Broughton, J.P.; Zhu, S.; Li, H.; Li, B.; Chen, L.; et al. m(6)A mRNA methylation sustains Treg suppressive functions. Cell Res. 2018, 28, 253-256. [CrossRef] [PubMed]

29. Geula, S.; Moshitch-Moshkovitz, S.; Dominissini, D.; Mansour, A.A.; Kol, N.; Salmon-Divon, M.; Hershkovitz, V.; Peer, E.; Mor, N.; Manor, Y.S.; et al. Stem cells. m6A mRNA methylation facilitates resolution of naive pluripotency toward differentiation. Science 2015, 347, 1002-1006. [CrossRef] [PubMed]

30. Engel, M.; Chen, A. The emerging role of mRNA methylation in normal and pathological behavior. Genes Brain Behav. 2017, 17, e12428. [CrossRef] [PubMed]

31. Kang, H.; Zhang, Z.; Yu, L.; Li, Y.; Liang, M.; Zhou, L. FTO reduces mitochondria and promotes hepatic fat accumulation through RNA demethylation. J. Cell. Biochem. 2018, 119, 5676-5685. [CrossRef] [PubMed]

32. Ding, C.; Zou, Q.; Ding, J.; Ling, M.; Wang, W.; Li, H.; Huang, B. Increased N6-Methyladenosine causes infertility is associated with FTO expression. J. Cell. Physiol. 2018, 233, 7055-7066. [CrossRef] [PubMed]

33. Wang, Y.; Li, Y.; Toth, J.I.; Petroski, M.D.; Zhang, Z.; Zhao, J.C. N6-methyladenosine modification destabilizes developmental regulators in embryonic stem cells. Nat. Cell Biol. 2014, 16, 191-198. [CrossRef] [PubMed]

34. Lichinchi, G.; Gao, S.; Saletore, Y.; Gonzalez, G.M.; Bansal, V.; Wang, Y.; Mason, C.E.; Rana, T.M. Dynamics of the human and viral m(6)A RNA methylomes during HIV-1 infection of T cells. Nat. Microbiol. 2016, 1, 16011. [CrossRef] [PubMed]

35. Fustin, J.M.; Doi, M.; Yamaguchi, Y.; Hida, H.; Nishimura, S.; Yoshida, M.; Isagawa, T.; Morioka, M.S.; Kakeya, H.; Manabe, I.; et al. RNA-methylation-dependent RNA processing controls the speed of the circadian clock. Cell 2013, 155, 793-806. [CrossRef] [PubMed]

36. Shen, H.; Shih, J.; Hollern, D.P.; Wang, L.; Bowlby, R.; Tickoo, S.K.; Thorsson, V.; Mungall, A.J.; Newton, Y.; Hegde, A.M.; et al. Integrated molecular characterization of testicular germ cell tumors. Cell Rep. 2018, 23, 3392-3406. [CrossRef] [PubMed]

37. Tusup, M.; Kundig, T.; Pascolo, S. Epitranscriptomics of cancer. World J. Clin. Oncol. 2018, 9, 42-55. [CrossRef] [PubMed]

38. Wang, S.; Chai, P.; Jia, R.; Jia, R. Novel insights on m(6)A RNA methylation in tumorigenesis: A double-edged sword. Mol. Cancer 2018, 17, 101. [CrossRef] [PubMed]

39. Batista, P.J.; Molinie, B.; Wang, J.; Qu, K.; Zhang, J.; Li, L.; Bouley, D.M.; Lujan, E.; Haddad, B.; Daneshvar, K.; et al. m(6)A RNA modification controls cell fate transition in mammalian embryonic stem cells. Cell Stem Cell 2014, 15, 707-719. [CrossRef] [PubMed]

40. Esteller, M.; Pandolfi, P.P. The epitranscriptome of noncoding RNAs in cancer. Cancer Discov. 2017, 7, 359-368. [CrossRef] [PubMed]

41. Liu, Z.X.; Li, L.M.; Sun, H.L.; Liu, S.M. Link between m6A modification and cancers. Front. Bioeng. Biotechnol. 2018, 6, 89. [CrossRef] [PubMed]

42. Wang, S.; Sun, C.; Li, J.; Zhang, E.; Ma, Z.; Xu, W.; Li, H.; Qiu, M.; Xu, Y.; Xia, W.; et al. Roles of RNA methylation by means of N(6)-methyladenosine (m(6)A) in human cancers. Cancer Lett. 2017, 408, 112-120. [CrossRef] [PubMed]

43. He, L.; Li, J.; Wang, X.; Ying, Y.; Xie, H.; Yan, H.; Zheng, X.; Xie, L. The dual role of N6-methyladenosine modification of RNAs is involved in human cancers. J. Cell Mol. Med. 2018, 22, 4630-4639. [CrossRef] [PubMed]

44. Lian, H.; Wang, Q.H.; Zhu, C.B.; Ma, J.; Jin, W.L. Deciphering the epitranscriptome in cancer. Trends Cancer 2018, 4, 207-221. [CrossRef] [PubMed] 
45. Xu, C.; Liu, K.; Tempel, W.; Demetriades, M.; Aik, W.; Schofield, C.J.; Min, J. Structures of human ALKBH5 demethylase reveal a unique binding mode for specific single-stranded N6-methyladenosine RNA demethylation. J. Biol. Chem. 2014, 289, 17299-17311. [CrossRef] [PubMed]

46. Li, G.; Chen, Q.; Wang, L.; Ke, D.; Yuan, Z. Association between FTO gene polymorphism and cancer risk: Evidence from 16,277 cases and 31,153 controls. Tumour Biol. 2012, 33, 1237-1243. [CrossRef] [PubMed]

47. Blanco, S.; Frye, M. Role of RNA methyltransferases in tissue renewal and pathology. Curr. Opin. Cell Biol. 2014, 31, 1-7. [CrossRef] [PubMed]

48. Iles, M.M.; Law, M.H.; Stacey, S.N.; Han, J.; Fang, S.; Pfeiffer, R.; Harland, M.; Macgregor, S.; Taylor, J.C.; Aben, K.K.; et al. A variant in FTO shows association with melanoma risk not due to BMI. Nat. Genet. 2013, 45, 428-432. [CrossRef] [PubMed]

49. Garcia-Closas, M.; Couch, F.J.; Lindstrom, S.; Michailidou, K.; Schmidt, M.K.; Brook, M.N.; Orr, N.; Rhie, S.K.; Riboli, E.; Feigelson, H.S.; et al. Genome-wide association studies identify four ER negative-specific breast cancer risk loci. Nat. Genet. 2013, 45, 392-398. [CrossRef] [PubMed]

50. Tan, A.; Dang, Y.; Chen, G.; Mo, Z. Overexpression of the fat mass and obesity associated gene (FTO) in breast cancer and its clinical implications. Int. J. Clin. Exp. Pathol. 2015, 8, 13405-13410. [PubMed]

51. Singh, B.; Kinne, H.E.; Milligan, R.D.; Washburn, L.J.; Olsen, M.; Lucci, A. Important role of FTO in the survival of rare panresistant triple-negative inflammatory breast cancer cells facing a severe metabolic challenge. PLoS ONE 2016, 11, e0159072. [CrossRef] [PubMed]

52. Zhang, C.; Zhi, W.I.; Lu, H.; Samanta, D.; Chen, I.; Gabrielson, E.; Semenza, G.L. Hypoxia-inducible factors regulate pluripotency factor expression by ZNF217- and ALKBH5-mediated modulation of RNA methylation in breast cancer cells. Oncotarget 2016, 7, 64527-64542. [CrossRef] [PubMed]

53. Zhang, C.; Samanta, D.; Lu, H.; Bullen, J.W.; Zhang, H.; Chen, I.; He, X.; Semenza, G.L. Hypoxia induces the breast cancer stem cell phenotype by HIF-dependent and ALKBH5-mediated m(6)A-demethylation of NANOG mRNA. Proc. Natl. Acad. Sci. USA 2016, 113, E2047-E2056. [CrossRef] [PubMed]

54. Cai, X.; Wang, X.; Cao, C.; Gao, Y.; Zhang, S.; Yang, Z.; Liu, Y.; Zhang, X.; Zhang, W.; Ye, L. HBXIP-elevated methyltransferase METTL3 promotes the progression of breast cancer via inhibiting tumor suppressor let-7g. Cancer Lett. 2018, 415, 11-19. [CrossRef] [PubMed]

55. Chen, M.; Wei, L.; Law, C.T.; Tsang, F.H.; Shen, J.; Cheng, C.L.; Tsang, L.H.; Ho, D.W.; Chiu, D.K.; Lee, J.M.; et al. RNA N6-methyladenosine methyltransferase METTL3 promotes liver cancer progression through YTHDF2 dependent post-transcriptional silencing of SOCS2. Hepatology 2017, 67, 2254-2270. [CrossRef] [PubMed]

56. Zhao, X.; Chen, Y.; Mao, Q.; Jiang, X.; Jiang, W.; Chen, J.; Xu, W.; Zhong, L.; Sun, X. Overexpression of YTHDF1 is associated with poor prognosis in patients with hepatocellular carcinoma. Cancer Biomark. 2018, 21, 859-868. [CrossRef] [PubMed]

57. Ma, J.Z.; Yang, F.; Zhou, C.C.; Liu, F.; Yuan, J.H.; Wang, F.; Wang, T.T.; Xu, Q.G.; Zhou, W.P.; Sun, S.H. METTL14 suppresses the metastatic potential of hepatocellular carcinoma by modulating $\mathrm{N}(6)$-methyladenosine-dependent primary microRNA processing. Hepatology 2017, 65, 529-543. [CrossRef] [PubMed]

58. Taketo, K.; Konno, M.; Asai, A.; Koseki, J.; Toratani, M.; Satoh, T.; Doki, Y.; Mori, M.; Ishii, H.; Ogawa, K. The epitranscriptome m6A writer METTL3 promotes chemo- and radioresistance in pancreatic cancer cells. Int. J. Oncol. 2018, 52, 621-629. [CrossRef] [PubMed]

59. Chen, J.; Sun, Y.; Xu, X.; Wang, D.; He, J.; Zhou, H.; Lu, Y.; Zeng, J.; Du, F.; Gong, A.; et al. YTH domain family 2 orchestrates epithelial-mesenchymal transition/proliferation dichotomy in pancreatic cancer cells. Cell Cycle 2017, 16, 2259-2271. [CrossRef] [PubMed]

60. Jo, H.J.; Shim, H.E.; Han, M.E.; Kim, H.J.; Kim, K.S.; Baek, S.; Choi, K.U.; Hur, G.Y.; Oh, S.O. WTAP regulates migration and invasion of cholangiocarcinoma cells. J. Gastroenterol. 2013, 48, 1271-1282. [CrossRef] [PubMed]

61. Nishizawa, Y.; Konno, M.; Asai, A.; Koseki, J.; Kawamoto, K.; Miyoshi, N.; Takahashi, H.; Nishida, N.; Haraguchi, N.; Sakai, D.; et al. Oncogene c-Myc promotes epitranscriptome m(6)A reader YTHDF1 expression in colorectal cancer. Oncotarget 2018, 9, 7476-7486. [CrossRef] [PubMed]

62. Tanabe, A.; Tanikawa, K.; Tsunetomi, M.; Takai, K.; Ikeda, H.; Konno, J.; Torigoe, T.; Maeda, H.; Kutomi, G.; Okita, K.; et al. RNA helicase YTHDC2 promotes cancer metastasis via the enhancement of the efficiency by which HIF-1alpha mRNA is translated. Cancer Lett. 2016, 376, 34-42. [CrossRef] [PubMed] 
63. Porcellini, E.; Laprovitera, N.; Riefolo, M.; Ravaioli, M.; Garajova, I.; Ferracin, M. Epigenetic and epitranscriptomic changes in colorectal cancer: Diagnostic, prognostic, and treatment implications. Cancer Lett. 2018, 419, 84-95. [CrossRef] [PubMed]

64. Xu, D.; Shao, W.; Jiang, Y.; Wang, X.; Liu, Y.; Liu, X. FTO expression is associated with the occurrence of gastric cancer and prognosis. Oncol. Rep. 2017, 38, 2285-2292. [CrossRef] [PubMed]

65. Wang, X.; Li, Z.; Kong, B.; Song, C.; Cong, J.; Hou, J.; Wang, S. Reduced m(6)A mRNA methylation is correlated with the progression of human cervical cancer. Oncotarget 2017, 8, 98918-98930. [CrossRef] [PubMed]

66. Zhou, S.; Bai, Z.L.; Xia, D.; Zhao, Z.J.; Zhao, R.; Wang, Y.Y.; Zhe, H. FTO regulates the chemo-radiotherapy resistance of cervical squamous cell carcinoma (CSCC) by targeting $\beta$-catenin through mRNA demethylation. Mol. Carcinog. 2018, 57, 590-597. [CrossRef] [PubMed]

67. Liu, J.; Eckert, M.A.; Harada, B.T.; Liu, S.M.; Lu, Z.; Yu, K.; Tienda, S.M.; Chryplewicz, A.; Zhu, A.C.; Yang, Y.; et al. m(6)A mRNA methylation regulates AKT activity to promote the proliferation and tumorigenicity of endometrial cancer. Nat. Cell Biol. 2018, 20, 1074-1083. [CrossRef] [PubMed]

68. Cui, Q.; Shi, H.; Ye, P.; Li, L.; Qu, Q.; Sun, G.; Sun, G.; Lu, Z.; Huang, Y.; Yang, C.G.; et al. m(6)A RNA methylation regulates the self-renewal and tumorigenesis of glioblastoma stem cells. Cell Rep. 2017, 18, 2622-2634. [CrossRef] [PubMed]

69. Zhang, S.; Zhao, B.S.; Zhou, A.; Lin, K.; Zheng, S.; Lu, Z.; Chen, Y.; Sulman, E.P.; Xie, K.; Bogler, O.; et al. $\mathrm{m}(6)$ A demethylase ALKBH5 maintains tumorigenicity of glioblastoma stem-like cells by sustaining FOXM1 expression and cell proliferation program. Cancer Cell 2017, 31, 591-606.e6. [CrossRef] [PubMed]

70. Visvanathan, A.; Patil, V.; Arora, A.; Hegde, A.S.; Arivazhagan, A.; Santosh, V.; Somasundaram, K. Essential role of METTL3-mediated $\mathrm{m}(6) \mathrm{A}$ modification in glioma stem-like cells maintenance and radioresistance. Oncogene 2018, 37, 522-533. [CrossRef] [PubMed]

71. Lin, S.; Choe, J.; Du, P.; Triboulet, R.; Gregory, R.I. The m(6)A methyltransferase METTL3 promotes translation in human cancer cells. Mol. Cell 2016, 62, 335-345. [CrossRef] [PubMed]

72. Du, M.; Zhang, Y.; Mao, Y.; Mou, J.; Zhao, J.; Xue, Q.; Wang, D.; Huang, J.; Gao, S.; Gao, Y. MiR-33a suppresses proliferation of NSCLC cells via targeting METTL3 mRNA. Biochem. Biophys. Res. Commun. 2017, 482, 582-589. [CrossRef] [PubMed]

73. Kwok, C.T.; Marshall, A.D.; Rasko, J.E.; Wong, J.J. Genetic alterations of m(6)A regulators predict poorer survival in acute myeloid leukemia. J. Hematol. Oncol. 2017, 10, 39. [CrossRef] [PubMed]

74. Weng, H.; Huang, H.; Wu, H.; Qin, X.; Zhao, B.S.; Dong, L.; Shi, H.; Skibbe, J.; Shen, C.; Hu, C.; et al. METTL14 inhibits hematopoietic stem/progenitor differentiation and promotes leukemogenesis via mRNA m(6)A modification. Cell Stem Cell 2018, 22, 191-205.e9. [CrossRef] [PubMed]

75. Barbieri, I.; Tzelepis, K.; Pandolfini, L.; Shi, J.; Millan-Zambrano, G.; Robson, S.C.; Aspris, D.; Migliori, V.; Bannister, A.J.; Han, N.; et al. Promoter-bound METTL3 maintains myeloid leukaemia by m(6)A-dependent translation control. Nature 2017, 552, 126-131. [CrossRef] [PubMed]

76. Vu, L.P.; Pickering, B.F.; Cheng, Y.; Zaccara, S.; Nguyen, D.; Minuesa, G.; Chou, T.; Chow, A.; Saletore, Y.; MacKay, M.; et al. The N(6)-methyladenosine (m(6)A)-forming enzyme METTL3 controls myeloid differentiation of normal hematopoietic and leukemia cells. Nat. Med. 2017, 23, 1369-1376. [CrossRef] [PubMed]

77. Bansal, H.; Yihua, Q.; Iyer, S.P.; Ganapathy, S.; Proia, D.A.; Penalva, L.O.; Uren, P.J.; Suresh, U.; Carew, J.S.; Karnad, A.B.; et al. WTAP is a novel oncogenic protein in acute myeloid leukemia. Leukemia 2014, 28, 1171-1174. [CrossRef] [PubMed]

78. Ma, Z.; Morris, S.W.; Valentine, V.; Li, M.; Herbrick, J.A.; Cui, X.; Bouman, D.; Li, Y.; Mehta, P.K.; Nizetic, D.; et al. Fusion of two novel genes, RBM15 and MKL1, in the $t(1 ; 22)(p 13 ; q 13)$ of acute megakaryoblastic leukemia. Nat. Genet. 2001, 28, 220-221. [CrossRef] [PubMed]

79. Casalegno-Garduno, R.; Schmitt, A.; Wang, X.; Xu, X.; Schmitt, M. Wilms' tumor 1 as a novel target for immunotherapy of leukemia. Transplant. Proc. 2010, 42, 3309-3311. [CrossRef] [PubMed]

80. Li, Z.; Weng, H.; Su, R.; Weng, X.; Zuo, Z.; Li, C.; Huang, H.; Nachtergaele, S.; Dong, L.; Hu, C.; et al. FTO plays an oncogenic role in acute myeloid leukemia as a N(6)-methyladenosine RNA demethylase. Cancer Cell 2017, 31, 127-141. [CrossRef] [PubMed]

81. Cairns, R.A.; Mak, T.W. Oncogenic isocitrate dehydrogenase mutations: Mechanisms, models, and clinical opportunities. Cancer Discov. 2013, 3, 730-741. [CrossRef] [PubMed] 
82. Elkashef, S.M.; Lin, A.P.; Myers, J.; Sill, H.; Jiang, D.; Dahia, P.L.M.; Aguiar, R.C.T. IDH Mutation, competitive inhibition of FTO, and RNA methylation. Cancer Cell 2017, 31, 619-620. [CrossRef] [PubMed]

83. Cerami, E.; Gao, J.; Dogrusoz, U.; Gross, B.E.; Sumer, S.O.; Aksoy, B.A.; Jacobsen, A.; Byrne, C.J.; Heuer, M.L.; Larsson, E.; et al. The cBio cancer genomics portal: An open platform for exploring multidimensional cancer genomics data. Cancer Discov. 2012, 2, 401-404. [CrossRef] [PubMed]

84. Center, M.M.; Jemal, A.; Lortet-Tieulent, J.; Ward, E.; Ferlay, J.; Brawley, O.; Bray, F. International variation in prostate cancer incidence and mortality rates. Eur. Urol. 2012, 61, 1079-1092. [CrossRef] [PubMed]

85. Ferlay, J.; Soerjomataram, I.; Dikshit, R.; Eser, S.; Mathers, C.; Rebelo, M.; Parkin, D.M.; Forman, D.; Bray, F. Cancer incidence and mortality worldwide: Sources, methods and major patterns in GLOBOCAN 2012. Int. J. Cancer 2015, 136, E359-E386. [CrossRef] [PubMed]

86. Roobol, M.J.; Carlsson, S.V. Risk stratification in prostate cancer screening. Nat. Rev. Urol. 2013, 10, 38-48. [CrossRef] [PubMed]

87. Shen, M.M.; Abate-Shen, C. Molecular genetics of prostate cancer: New prospects for old challenges. Genes Dev. 2010, 24, 1967-2000. [CrossRef] [PubMed]

88. Ceder, Y.; Bjartell, A.; Culig, Z.; Rubin, M.A.; Tomlins, S.; Visakorpi, T. The molecular evolution of castration-resistant prostate cancer. Eur. Urol. Focus 2016, 2, 506-513. [CrossRef] [PubMed]

89. Sardana, G.; Diamandis, E.P. Biomarkers for the diagnosis of new and recurrent prostate cancer. Biomark. Med. 2012, 6, 587-596. [CrossRef] [PubMed]

90. Chiam, K.; Ricciardelli, C.; Bianco-Miotto, T. Epigenetic biomarkers in prostate cancer: Current and future uses. Cancer Lett. 2014, 342, 248-256. [CrossRef] [PubMed]

91. Li, J.; Meng, S.; Xu, M.; Wang, S.; He, L.; Xu, X.; Wang, X.; Xie, L. Downregulation of N6-methyladenosine binding YTHDF2 protein mediated by miR-493-3p suppresses prostate cancer by elevating N6-methyladenosine levels. Oncotarget 2018, 9, 3752-3764. [PubMed]

92. Moch, H.; Cubilla, A.L.; Humphrey, P.A.; Reuter, V.E.; Ulbright, T.M. The 2016 WHO classification of tumours of the urinary system and male genital organs-part A: Renal, penile, and testicular tumours. Eur. Urol. 2016, 70, 93-105. [CrossRef] [PubMed]

93. Trabert, B.; Chen, J.; Devesa, S.S.; Bray, F.; McGlynn, K.A. International patterns and trends in testicular cancer incidence, overall and by histologic subtype, 1973-2007. Andrology 2015, 3, 4-12. [CrossRef] [PubMed]

94. Beyer, J.; Albers, P.; Altena, R.; Aparicio, J.; Bokemeyer, C.; Busch, J.; Cathomas, R.; Cavallin-Stahl, E.; Clarke, N.W.; Classen, J.; et al. Maintaining success, reducing treatment burden, focusing on survivorship: Highlights from the third European consensus conference on diagnosis and treatment of germ-cell cancer. Ann. Oncol. 2013, 24, 878-888. [CrossRef] [PubMed]

95. Costa, A.L.; Lobo, J.; Jeronimo, C.; Henrique, R. The epigenetics of testicular germ cell tumors: Looking for novel disease biomarkers. Epigenomics 2017, 9, 155-169. [CrossRef] [PubMed]

96. Lobo, J.; Costa, A.L.; Vilela-Salgueiro, B.; Rodrigues, A.; Guimaraes, R.; Cantante, M.; Lopes, P.; Antunes, L.; Jeronimo, C.; Henrique, R. Testicular germ cell tumors: Revisiting a series in light of the new WHO classification and AJCC staging systems, focusing on challenges for pathologists. Hum. Pathol. 2018. [CrossRef] [PubMed]

97. Henrique, R.; Jeronimo, C. Testicular germ cell tumors go epigenetics: Will miR-371a-3p replace classical serum biomarkers? Eur. Urol. 2017, 71, 221-222. [CrossRef] [PubMed]

98. Aoun, F.; Kourie, H.R.; Albisinni, S.; Roumeguere, T. Will testicular germ cell tumors remain untargetable? Target Oncol. 2016, 11, 711-721. [CrossRef] [PubMed]

99. Boccellino, M.; Vanacore, D.; Zappavigna, S.; Cavaliere, C.; Rossetti, S.; D’Aniello, C.; Chieffi, P.; Amler, E.; Buonerba, C.; Di Lorenzo, G.; et al. Testicular cancer from diagnosis to epigenetic factors. Oncotarget 2017, 8, 104654-104663. [CrossRef] [PubMed]

100. Murray, M.J.; Huddart, R.A.; Coleman, N. The present and future of serum diagnostic tests for testicular germ cell tumours. Nat. Rev. Urol. 2016, 13, 715-725. [CrossRef] [PubMed]

101. Van Der Zwan, Y.G.; Stoop, H.; Rossello, F.; White, S.J.; Looijenga, L.H. Role of epigenetics in the etiology of germ cell cancer. Int. J. Dev. Biol. 2013, 57, 299-308. [CrossRef] [PubMed]

102. Wilkinson, P.M.; Read, G. International Germ Cell Consensus Classification: A prognostic factor-based staging system for metastatic germ cell cancers. International Germ Cell Cancer Collaborative Group. J. Clin. Oncol. 1997, 15, 594-603. [CrossRef] 
103. Ferlay, J.; Steliarova-Foucher, E.; Lortet-Tieulent, J.; Rosso, S.; Coebergh, J.-W.W.; Comber, H.; Forman, D.; Bray, F. Cancer incidence and mortality patterns in Europe: Estimates for 40 countries in 2012. Eur. J. Cancer 2013, 49, 1374-1403. [CrossRef] [PubMed]

104. Ljungberg, B.; Bensalah, K.; Canfield, S.; Dabestani, S.; Hofmann, F.; Hora, M.; Kuczyk, M.A.; Lam, T.; Marconi, L.; Merseburger, A.S. EAU guidelines on renal cell carcinoma: 2014 update. Eur. Urol. 2015, 67, 913-924. [CrossRef] [PubMed]

105. Li, X.; Tang, J.; Huang, W.; Wang, F.; Li, P.; Qin, C.; Qin, Z.; Zou, Q.; Wei, J.; Hua, L. The M6A methyltransferase METTL3: Acting as a tumor suppressor in renal cell carcinoma. Oncotarget 2017, 8, 96103-96116. [CrossRef] [PubMed]

106. Torre, L.A.; Bray, F.; Siegel, R.L.; Ferlay, J.; Lortet-Tieulent, J.; Jemal, A. Global cancer statistics, 2012. CA Cancer J. Clin. 2015, 65, 87-108. [CrossRef] [PubMed]

107. Antoni, S.; Ferlay, J.; Soerjomataram, I.; Znaor, A.; Jemal, A.; Bray, F. Bladder cancer incidence and mortality: A global overview and recent trends. Eur. Urol. 2017, 71, 96-108. [CrossRef] [PubMed]

108. Sanli, O.; Dobruch, J.; Knowles, M.A.; Burger, M.; Alemozaffar, M.; Nielsen, M.E.; Lotan, Y. Bladder cancer. Nat. Rev. Dis. Primers 2017, 3, 17022. [CrossRef] [PubMed]

(C) 2018 by the authors. Licensee MDPI, Basel, Switzerland. This article is an open access article distributed under the terms and conditions of the Creative Commons Attribution (CC BY) license (http:/ / creativecommons.org/licenses/by/4.0/). 